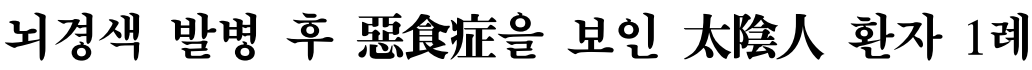

\author{
김민지 · 배효상 · 박성식 \\ 동국대학교 한의과대학 $\wedge$ 상체질과
}

\section{Abstract \\ A Case Study of Taeeumin Patient Who Experienced Refusing Food Intake after Stroke}

\author{
Min-Ji Kim, Hyo-Sang Bae, and Seong-Sik Park \\ Dept. of Sasang Constitutional Medicine, College of Oriental Medicine, Dongguk Univ.
}

\section{Objectives}

The purpose of this case thesis paper is to report the improvement of symptoms for a 58 -year-old male patient who experienced refusing food intake 1 month after onset of stroke by treating the patient with Chungpyesagan-tang

\section{Methods}

We have determined the patient to have the Taeeumin type physique with Dry Heat Syndrome and provided Chungpyesagan-tang to alleviate the patient's symptoms. The level of improvement was measured based on changes of food intake amount.

\section{Results}

The patient was hospitalized to receive treatment for roughly 2 weeks. The symptom of refusing food intake as well as other symptoms that simultaneously appeared including insomnia, headache, dizziness, and general weakness have improved.

\section{Conclusions}

In this case, the symptom of refusing food intake appeared one month after experiencing stroke, and the patient refused not only meals, but the intake of all other forms of food including water and medicine. The cause of such symptoms were deemed to be emotional rather than the types of food which generally provide the causes for Oh Shik Jeung. As the patient was deemed to have the Taeeumin type physique with Dry Heat Syndrome. Chungpyesagan-tang was provided for treatment. Acupuncture and oriental cupping therapy were also provided concurrently, and the main symptom and other accompanying conditions have largely improved after 2 weeks of hospitalized treatment.

Key Words: Refusing food intake, Stroke, Taeeumin, Dry Heat Syndrome, Chungpyesagan-tang

Received February 07, 2013 Revised February 12, 2013 Accepted March 06, 2013 Corresponding Author Seong-Sik Park

Dept. of Sasang Constitutional Medicine, Bundang orient medical hospital of Dongguk university,

87-2, Sunae 3-dong, Bundang-gu, Seoungnam-si, Gyeonggi-do, 463-865, Rep, of Korea

Tel : +82-31-710-3723 Fax :+82-31-710-3780 E-mail : parkss@dongguk.ac.kr
(C) The Society of Sasang Constitutional Medicine. All rights reserved. This is an open acess article distributed under the terms of the Creative Commons attribution Non-commercial License (http:// creativecommons.org/licenses/by-nc/3.0/) 


\section{I. 緒 論}

惡食은 음식을 보면 싫어하여 먹지 않는 경우를 가리키는 말로『醫宗金鑑』, 『醫學入門』, 『景岳全 書』등에서 惡食의 원인을 공통적으로 傷食으로 보 았다. ${ }^{2,3,4}$ 그러나 李用粹는 『證治彙補』에서 惡食 의 원인을 傷食뿐만 아니라 胸中痰滞, 傷食, 病久 胃虛 로 나누어 좀 더 자세히 설명하였다. ${ }^{5}$ 본 증례는 뇌경색 발병 한 달 후 갑자기 惡食症을 보여 입원치 료를 받은 환자의 증례이다.

뇌졸중 후 발생할 수 있는 후유증에는 인지기능장 애, 시각장애, 지각장애, 언어장애, 강직, 삼킴곤란, 통 증, 낙상과 골절 등이 있으며, ${ }^{6}$ 다른 연구보고에 따르 면 뇌졸중으로 입원치료를 받은 환자들에서 변비, 견 갑통, 소화장애 등의 증상이 주로 나타날 수 있고 이 외에도 흉부감염, 요로계 감염, 발열, 두통, 불면 등의 증상을 수반할 수 있다고 하였다. 뇌졸중 후 발생할 수 있는 다양한 증상들에 대한 연구가 있었지만 惡食 症에 대한 증례나 이에 대한 언급은 찾아보기가 어려 웠다.

이에 저자는 뇌졸중 후에 주로 나타나는 후유증이 나 합병증의 양상과는 달리 뇌졸중 후 惡食症이 발생 한 환자를 기존에 제시된 胸中痰滯, 傷食, 病久胃 虛 등의 원인 이외에 性情의 偏急으로 인해 생긴 太陰人 燥熱證으로 진단하여 淸肺瀉肝湯을 투여 하였고 2주간 입원 치료 후 주소증 및 제반 증상이 호전되었기에 보고하는 바이다.

\section{II. 症 例}

1. 환자 : 조 $\bigcirc(\mathrm{M} / 58)$

2. 발병일 : 2012년 11월 24일

3. 치료기간 : 2012년 11월 26일 - 2012년 12월 8일 (13일간)
4. 진단명 : 상세불명의 뇌경색증

중풍후유증

5. 주소증 : 惡食症(식사 거부) 不眠

6. 부증상: 氣力低下, 頭痛, 眩暈, 神經言語障碍

\section{7. 과거력}

1) 버거씨병 : 20 년전 진단

2) 심근경색 : 2001년 진단

3) 뇌경색 : 2003년 진단, 입원치료 받음

4) 척골신경병증 : 2012년 8월, 10월 2차례 수술함

5) 당뇨 : 2012년 11 월 진단 약복용 (+)

8. 가족력 : 특이사항 없음

\section{9. 현병력}

상기환자는 0 O양방병원에서 2012년 10월 30일 Lt. MCA region에 Acute Cbr. infarction 진단받고 약 2 주간 입원 치료 후에 증상 안정되어 퇴원해 10 일간 가료하던 환자로 본원에 내원하기 2 일 전부터 갑자기 식사 및 모든 음식물 섭취에 대한 거부 증상과 불면 등의 증상을 보이기 시작하여 이에 대한 검사 및 한방 치료 위해 본원 사상체질과에 내원함.

\section{0. 체질소견}

1)體形氣像 : $171 \mathrm{~cm}$ 의 키에 체중은 $75 \mathrm{~kg}$ 으로 전체적 으로 건장한 편이다.

(1) 액와 횡문간 거리: $33 \mathrm{~cm}$

(2) 양유두간의 횡행직선상 거리: $35.5 \mathrm{~cm}$

(3) 제 7,8 협늑골 접합부 횡행직선상 거리 : $31 \mathrm{~cm}$

(4) 신궐혈-천추혈 횡행직선상 거리 : $27.4 \mathrm{~cm}$

(5) ASIS 연결 횡행직선상 거리 : $32 \mathrm{~cm}$ 


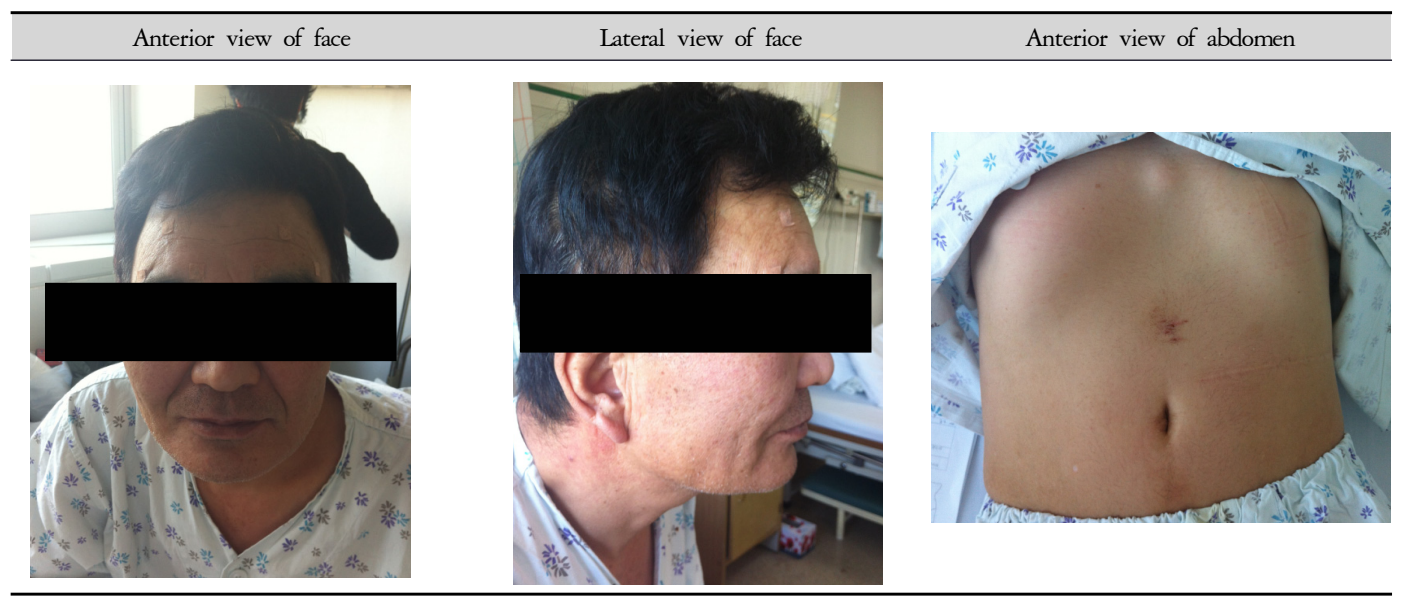

Figure 1. Face and abdomen of patient

\section{2) 容貌詞氣 (Figure 1)}

얼굴이 넓고 각이 져 있으며 얼굴색은 약간 검붉은 색을 띤다.

\section{3) 性質才幹}

성격이 급하고 화를 잘 내며 말이 빠르다.

\section{4) 素證}

(1) 睡眠 : 평소 수면에 큰 문제없음

(2) 食慾, 消化 : 1공기/1끼 정도, 소화상태 보통

(3) 大便 : 1회/1일, 보통 변

(4) 小便 : 4 5회/1일, 소변량 정상

(5) 汗出 : 평소에 약간 많은 편, 매운 음식을 먹으면 땀이 비 오듯 흐른다고 함

5) 의사결정나무법에 따른 체질분류 결과 : 太陰人 이상의 결과를 토대로 사상체질과 전문의와 상의 하여 太陰人으로 판단하였다.

\section{1. 초진소견}

1) 睡眠 : 수면상태 불량, 밤낮을 가리지 않고 계속 졸리며 잠만 자고 싶다고 함. 그러나 실제로는
깊이 잠들지 못하고 자다 깨다 하는 상태임

2) 食慾, 消化 : 내원 2 일 전부터 식사 거부하여 아무것도 먹지 않음.

3) 大便 : 1회/2일, 보통변

4) 小便 : 3 4회/1일, 소변량 약간 감소

5) ㅁ渴 : 입마름 증상이 약간 있으나 심하지는 않음

6) 汗出 : 약간 많은 편임.

7) 舌診 : 舌紅台白厚, 舌裂

8) 脈診: 脈弦, 緊

9) 肋骨角 : $100^{\circ}$

\section{2. 검사소견}

\section{1) 영상의학적 검사}

\section{$<2012.11 .27>$ Brain CT}

Subacute infarct in Lt. temporoparietal region. No evidence of newly developed lesion. Others, no interval change.

\section{2) 일반 병리 검사}

$<2012.11 .27>$

CEA : 4.48 (참고치 흡연 0 10) 
Table 1. Composition of Chungpyesagan-tang

\begin{tabular}{ccc}
\hline Herb & Scientific name & $\operatorname{dose}(\mathrm{g})$ \\
\hline 갈근 & Radix Puerariae & 16 \\
황금 & Radix Scutellariae & 8 \\
고본 & Radix Ligustici Tenuissimae & 8 \\
나복자 & Semen Raphani & 4 \\
길경 & Radix Platycodi & 4 \\
승마 & Rhizmoma Cimicifugae & 4 \\
백지 & Radix Angelicae Dahurica & 4 \\
대황 & Rhei Radix Rhixoma & 4 \\
총량 & & 52 \\
\hline
\end{tabular}

AFP : 4.38 (참고치 below 7.0)

CA19-9 : 12.46(참고치 below 34)

Lipase : 15.8 (참고치 13.0-60.0)

Amylase 48 (참고치28 100)

$\mathrm{CRP}: 1.8$ (참고치1.0 3.0)

$\mathrm{Cl}: 95 \downarrow \quad$ (참고치 96 106)

$\mathrm{K}: 4.5 \quad$ (참고치 $3.5 \sim 4.5$ )

$\mathrm{Na}: 132 \downarrow \quad$ (참고치 133 143)

Free T4 : 1.16 (참고치 $0.76 \sim 1.79$ )

$\mathrm{T} 3: 0.78$ (참고치0.63 2.00)

$\mathrm{TSH}: 1.19$ (참고치0.27 4.20)

\section{3) 혀의 미각 및 통각 검사}

$<2012.11 .28>$

환자의 눈을 가리고 소금, 설탕, 고추장 등을 환자 의 혀의 3 부위 이상에 찍어서 맛을 맞히게 함. 모두 정상 소견 보였음

혀에 $25 * 40$ 침을 사용하여 3 부위 이상 자침한 결과 모두 통증에 정상적인 반응을 보였음

\section{4) 우울증 검사(BDI test)1)}

$<2012.11 .28>$

33점으로 심한 우울상태에 해당함.

1) $\mathrm{BDI}$ 는 Beck depression inventory 의 줄임말로 우울증의 유형과 정도를 측정할 수 있다. 21개 문항, 0-3점 척도로 구성되어 있다. (0-9점 : 우울하지 않은 상태, 10-15점: 가벼운 우울상태, 16-23점: 중한 우울상태, 24-63점: 심한 우울상태)

\section{5) 치매검사(MMSE-K)2)}

$<2012.11 .28>$

21점으로 치매가 의심되는 상태에 해당함.

\section{3. 치료}

\section{1) 鍼炎治療}

직경 $0.25 \mathrm{~mm}$, 길이 $40 \mathrm{~mm} 1$ 회용 stainless 호침(동방 침구)을 사용하여 太院人 太極鍼法인 靈道(補), 太 淵(補), 太衝(瀉) 등에 1 일 1 회 자침하였고, 15 분간 留銊하였다. 그리고耳鍼 혈자리 중 神門, 心, 腎 등의 穴에 皮內銊을 자입하였다.

또한 中脘穴에 間接尒(神氣尒)를 1 狀坐 1 일 1 회 시술하였으며, 肝腧, 膽骰, 脾骰, 胃腧 등의 背骰 穴에 부항을 5 분간 1 일 1 회 시술하였다.

\section{2) 韓藥治療}

太陰人 肝受熱裏熱病으로 변증하여 淸肺瀉肝 湯 을 처방하였다. 입원시에는 1 日 2貼을 전탕하여 $120 \mathrm{cc}$ 씩 하루 3 회 복용하도록 하였다. 그리고 牛黃淸 心丸을 매일 1알씩 복용하도록 하였다. 또한 퇴원약 으로 淸肺瀉肝湯 20貼을 전탕하여 하루 2회씩 15일 간 복용하도록 하였다. 淸肺瀉肝湯의 구성은 다음 과 같다. (Table 1)

2) MMSE-K는 Mini mental state examination-Korea의 줄임말로 치매선별검사도구이다. 총 30점 만점이다.(24점 이상 : 정상, 20 23: 치매가 의심되는 상태, 15 19: 경증의 치매 가 의심, 14 점 이하 : 중증의 치매가 의심) 


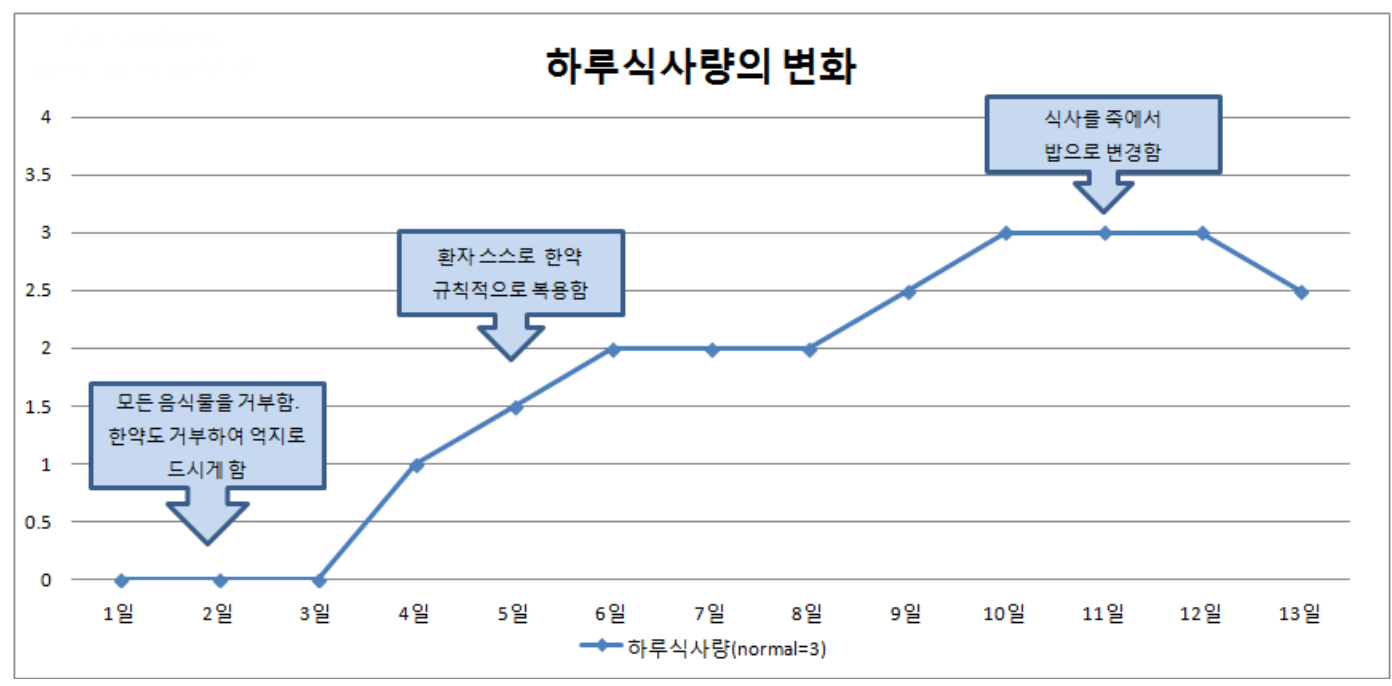

Figure 2. Change of patient's food intake amount for a day (' 1 ' means a bowl of rice)

Table 2. Change of Symptoms

\begin{tabular}{|c|c|c|c|c|c|c|c|}
\hline 입원일수 & 1일째 & 3일째 & 5일째 & 7일째 & 9일째 & 11일째 & 13일째 \\
\hline \multicolumn{8}{|l|}{ 증상 } \\
\hline $\begin{array}{l}\text { 식사 및 약 } \\
\text { 복용 거부 }\end{array}$ & +++ & +++ & ++ & + & + & \pm & - \\
\hline 식사량 & 全無 & 全無 & 죽 $1 / 2$ 공기 $/ 1$ 끼 & 죽 $2 / 3$ 공기/1끼 & 죽 $2 / 3$ 공기 $/ 1$ 끼 & 밥1공기/1끼 & 밥 $2 / 3$ 공기/1끼 \\
\hline 두통 & ++ & ++ & + & + & & & \\
\hline 현훈 & ++ & ++ & \pm & - & - & - & - \\
\hline 기력저하 & ++ & ++ & + & + & \pm & - & - \\
\hline 불면 & +++ & +++ & ++ & ++ & ++ & + & + \\
\hline
\end{tabular}

$+++:$ severe, ++ : moderate, $+:$ mild, \pm : trace, - : elimination

\section{4. 치료경과 (Figure 2, Table 2)}

\section{1) 입원 1일째}

환자는 뇌경색으로 2 주간 입원치료를 받고 퇴원하 여 별 문제없이 지내다가 본원에 내원하기 2일 전부터 갑자기 모든 음식의 섭취를 거부하는 증상을 보였다. 밥뿐만 아니라 약도 먹기 싫다고 하였으며 물조차도 거의 먹지 않았다. '밥맛이 이상하여 밥을 먹을 수가 없다.' '밥 생각만 해도 싫다라고 이야기하였다. 또한 며칠 전부터 하루 종일 졸리고 잠이 온다고 하며 계속 누워 있으려 하였으나 실제로는 깊은 잠을 자지 못해 서 많이 예민해진 상태였다. 전신에 기운이 없고 힘이
빠지는 듯하고 어지러우며 머리도 아프다고 하였다. 환자는 뇌경색 발병이후 반신마비 등의 증상은 없었 으나 신경언어장애 증상이 생겼으며 이로 인해 말은 할 수 있지만 종종 본인이 말하고자 하는 단어와 다른 단어를 사용하여 이야기하였기 때문에 의사소통에 문 제가 있는 상태였다.

\section{2) 입원 2일째 입원 3일째}

뇌경색의 재발을 의심하여 입원 2일째 Brain CT 검사를 시행하였다. 그러나 새로운 병변은 발견되지 않았다. 혈액 검사상에서도 다른 질환을 의심할만한 
결과가 나오지 않았다. 미각에 이상이 있는지를 판별 하기 위하여 혀의 미각 및 감각 검사를 시행하였으나 결과는 정상이었다. 환자는 입원 2,3 일째에도 식사를 전혀 하지 않았으며 여전히 밥을 먹기가 싫다고 말하 였으며 한약 복용도 거부하여 억지로 먹게 하였다. 밤에 잠을 제대로 자지 못하고 예민해져서 쉽게 화를 내는 상태였으며 계속 머리가 아프고 기운이 없다고 하였다.

입원 3 일째 우울증 검사인 $\mathrm{BDI}$ test와 치매검사인 MMSE-K 검사를 시행하였는데 심한 우울상태와 치매 의심 상태로 진단되었다.

환자가 음식물을 거의 섭취하지 않았기 때문에 수 분과 영양소의 보충을 위해 수액치료를 겸하였다.

\section{3) 입원 4일째}

입원 4일째 아침에 환자는 식사를 거부한지 6일 만에 처음으로 밥을 먹었다. 그러나 그 날 오후부터 환자는 다시 밥맛이 이상해서 먹을 수가 없다고 이야 기하며 식사를 거부하였다. 6일 만에 처음으로 식사 를 하였지만 복통이나 오심 등의 소화불량 증상을 호소하지 않았고 소화 상태에도 크게 문제가 없는 듯하였다.

\section{4) 입원 5 일째}

입원 5 일째부터 죽을 먹기 시작하여 끼니마다 죽 $1 / 2$ 정도로 소량씩 식사를 하기 시작하였으며 한약도 스스로 복용하였다. 식사를 하기 시작하면서 眩暈 증 상이 거의 소실되었고 氣力低下도 조금씩 회복되는 양상을 보였다.

\section{5) 입원 6일째 입원 10 일째}

환자는 입원 10 일째 까지 매 끼니 죽 1/2 1 공기 정도씩 식사를 규칙적으로 하기 시작했다. 환자가 입 원 당시 호소하던 眩暈 증상은 모두 소실되었고 頭痛 만 약간 남아있는 상태였다. 그러나 수면 상태는 여전 히 안정되지 못하고 하루는 숙면을 취하기도 하고 다
음 날은 또 제대로 자지 못하는 상태가 반복되었다. 환자의 언어장애 증상이 여전하여 원활한 의사소통이 어려웠다.

\section{6)입원 11일째 입원 13일째(퇴원일)}

입원 11일째 저녁부터 밥으로 식사를 하기 시작하 였다. 이후로 매 끼니 2/3 1공기 정도로식사량도 양 호하였으며 氣力低下 증상도 소실되었다. 잠을 거의 자지 못하던 입원 당시에 비하면 수면 시간이나 수면 의 질 또한 상당히 호전되었으나 새벽에 깨거나 밤늦 게 잠드는 등 숙면을 취하지는 못했다. 퇴원일 당시 식사량 밥 1 공기 정도로 양호하였으며 입원당시 보였 던 眩量, 頭痛, 氣力低下 등의 증상도 소실되었다.

\section{7) 퇴원 2주 후 (전화추적)}

퇴원 2주 후 전화로 환자의 상태를 확인했을 때, 환자는 끼니마다 밥 1 공기 정도로 정상적인 식사량을 유지하고 있으며 수면상태도 양호하다고 하였다.

\section{III. 考察 哭 結論}

식욕은 음식을 먹고 싶어 하는 욕망으로 모든 동물 은 필요에 따라서 식욕이 일어나 먹는 행동이 일어나 게 된다. ${ }^{8} \mathrm{KCD}$ (Korean Standard Classification of Piseas e) 3 ) 에서는 음식 및 수액 섭취에 관계된 증상에 관하 여 식욕부진, 다음다갈증, 다식증 등으로, 섭식장애 에 대해서는 신경성 식욕부진, 폭식증 등으로 식욕 및 음식 섭취에 문제가 있는 경우를 분류하였다.

이 중, 식욕의 저하를 일으킬 수 있는 질환에는 위 장계 질환으로는 장질환, 급성간염 등이 있고 정신적 장애로는 우울증, 식욕부진 등이 있으며 전신장애로 는 악성질환, 감염, 내분비대사질환 및 중독 등을 들 수 있다. ${ }^{9}$ 한방에서는 식욕 저하에 대하여 食㥕不振

3) $\mathrm{KCD}$ 는 한국표준질병 - 사인분류로 $\mathrm{ICD}$ (국제질병분류) 에 기초로 하고 한국 실정을 가미한 상병명 분류체계이다. 
이라는 단어로 포괄적으로 설명하였으며 不思食, 不 嘹食, 不能食, 惡食 등으로 표현하였다. ' 이 중 惡食 은 음식을 보면 싫어하여 먹지 않는 경우를 가리키는 용어인데, 『東醫寶鑑』 ${ }^{10}$ 에는 惡食이라는 단어가 없 었고 대신 不思食, 不嗜食 등으로 식욕이 저하된 증상을 표현하였으며『黃帝內經』이나『傷寒論』에 서는 惡食이라는 단어를 찾아볼 수 없었다.4)

惡食에 대해 언급한 문헌에서는 惡食의 원인이 주로 傷食에 있다고 보았는데, 이에 대하여 구체적으 로『醫宗金鑑』에서는 “惡食不食乃內傷拎食 胃 有宿滯也”라 하였고, 『景岳全書』 ${ }^{4}$ 에서도 “傷食者 必惡食” 이라 하여 공통적으로 傷食을 원인으로 들 었다. 그러나『證治彙補』에서는 그 원인을 傷食 뿐만 아니라 胸中痰滯, 傷食, 病久胃虛 등으로 구체적으로 제시하였으며 치료법에 있어서는 人䓄 과 白术 등으로 健脾시켜야 한다고 하였다. 최근 中醫學 에서는 “食慾不振 甚者惡聞食臭, 見食 物則惡心, 乃至嘔惡欲吐, 則稱惡食, 厭食”이라

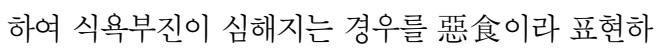
기도 한다. ${ }^{11}$

본 증례의 환자는 내원 1 달 전 좌측 중대뇌동맥 부위에 급성뇌경색을 진단받고 약 2 주간 양방병원에 서 입원치료 받은 후 퇴원하여 가료하던 환자로 본원 에 내원하기 2일전부터 갑자기 식사를 거부하는 증상 을 보였다. 입원 당시 환자는 식사뿐만 아니라 물도 거의 먹지 않는 상태로 '밥 생각만 해도 싫다' '밥을 먹을 수가 없다 라고 표현하였으며 이와 더불어 자 眠, 頭痛, 眩暈, 氣力低下 등의 증상도 동반하였다.

뇌경색의 재발에 가능성을 두고 입원 2일째 Brain CT 검사를 시행하였으나, 급성 뇌경색의 병변은 찾을 수 없었고, 혈액 검사 상에서도 위장질환, 간담질환, 갑상선질환, 악성질환 등을 의심할 만한 결과는 나오 지 않았다. 이 후 환자의 식사 거부의 원인이 혀의 문제에 있는지를 의심하여 소금, 설탕 등으로 혀의

4) http://youl.net/data/에서 제공된 『黃帝內經』, 『傷寒論』, 『東醫寶鑑』의 원문 파일을 이용하여 ‘惡食', ‘惡食'의 단어를 검색하였다.
미각이 정상인지를 검사하고 혀에 자침을 하여 감각 이 정상인지를 검사하였는데 모두 정상적인 반응을 보였다.

본 환자가 뇌경색 발병 후 다른 질환이 추가적으로 발생하지 않았음에도 불구하고 惡食, 不眠 등의 증 상을 보이게 된 원인을 정신적인 스트레스에서 비롯 된 것으로 판단하였고, 이에 우울증 검사를 시행한 결과, $\mathrm{BDI}$ test에서 33점으로 환자가 심한 우울상태에 해당함을 확인하였다. 또한 환자가 경미한 인지장애 를 보이고 단어구사력이 저하되어 있어 치매검사를 시행하였는데 그 결과 21점으로 치매 의심상태에 해 당하여 치매 정도가 심한상태가 아님을 알 수 있었다. 환자는 뇌졸중 발병 이후 반신마비 등의 운동장애는 없었으나 신경언어장애로 인해 자신이 말하고자 하는 단어와 다른 단어를 사용해 말을 하여 원활한 의사소 통이 어려웠고, 경미한 인지기능 저하를 보여 이로 인한 좌절 및 가족과의 마찰, 직장 복귀 문제, 금전적 인 문제 등으로 갈등을 겪고 있었는데 이러한 상황들 이 환자의 우울한 상태를 유발하였다고 볼 수 있다.

본 환자가 호소하는 惡食症은 일반적인 식욕부진 의 증상과는 달리 식사뿐만 아니라 물, 약 등 모든 음식물 섭취를 전적으로 거부하였으며, 신경성 식욕 부진증과 비교하였을 때 심인적, 정신적 장애로 인하 여 야기된 심각한 식욕부진 ${ }^{12}$ 을 보인다는 점에서는 유사하였지만, 거식증의 진단에 필요한 체중증가에 대한 강한 공포, 신체상의 장애 등이 없다는 점 ${ }^{13}$ 이

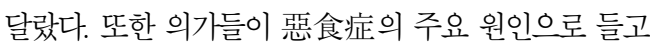
있는 傷食에서 비롯된 것이 아니라 性情의 偏急으 로부터 증상이 생긴 점이 특이하다고 볼 수 있다. 그리 고 『醫學入門 ${ }^{3}$ 에서는 七情에 상하면 비록 배가 불 러도 먹는 것을 싫어하지는 않는다5) 라고 하였었는데 이 환자의 경우는 이와 다르게 七情傷으로 惡食症 이 유발되었다.

본 증례의 환자는 $\mathrm{BDI}$ test에서 심한 우울증에 해당 하는 결과가 나왔었는데, 뇌졸중 환자의 경우 그 후유

5) 鿀學入門』「傷」...但傷食惡食, 七情作飽亦不惡食. 
증으로 우울증이 생길수가 있으며 우울증의 유병률은 급성기의 경우 $40 \%$, 만성기에는 $18 \sim 5 \%$ 정도라고 한다. 그리고 우울증의 증상은 수면장애, 식욕이나 성옥 감퇴, 식물성 불안징후, 주관적인 무력증과 같은 자율장애로 나타날 수 있다. ${ }^{6}$ 우울증이 생기는 기전 에 대해서는 뇌졸중이 직접 기분에 관여하는 신경회 로에 작용하는 이론과 뇌졸중과 관련된 사회-정신-생 리적 스트레스가 우울증의 원인이라는 이론이 대립 되고 있다. ${ }^{14}$

우울증으로 인해 ‘惡食症”이 생겼다고 단정 지을 수는 없지만 환자가 호소하는 일련의 증상들을 중풍 후유증으로 오는 우울증의 범주로도 볼 수 있을 것으 로 생각한다.

의사결정나무, 용모사기, 체형기상 등을 바탕으로 환자를 太陰人으로 진단하였고, 환자가 쉽게 화를 내고 짜증을 내며 예민해져 있는 점, 面色이 검붉고 舌苔가 두꺼운 점, 우울증 검사 결과 등을 고려하여 환자의 惡食症을 性情의 偏急에서 비롯된 太院人 燥熱證으로 진단하여 환자에게 淸肺瀉肝湯을 투 여하였다.

東武는 『東醫壽世保元』「醫源論」에서 옛날 의사들은 사람의 愛惡所欲, 喜怒哀樂이 지나친 것 이 병이 됨을 알지 못한다()고 하였으며「太陽人 內 觸小腸病論」에서 性이 深着하면 表氣를 상하고 情이 폭발하면 裹氣를 상한다7)고 하였다. 이는 본 증례에서 惡食症의 원인을 性情의 偏急으로 진단 한 근거로 볼 수 있으며「太陰人 肝受熱裏熱病論」 에서 太陰人의 面色이 黃, 赤, 黑색일 경우에는 燥 症이 있는 경우가 많다8)라고 한 점 또한 燥熱證의 진단 근거로 제시할 수 있다.

환자에게 투여한 淸肺瀉肝湯은 熱多寒少湯에

6) 『東醫壽世保元 辛丑本』醫源論」5-5 蓋古之醫師 不知 心之愛惡所欲 喜怒哀樂偏着者 爲病而但知脾胃水穀 風寒暑濕觸犯者 爲病.

7) 『東醫壽世保元 辛丑本』「太陽人內觸小腸病論」 15-10 太陽人哀心深着則 傷表氣怒心暴發則 傷裏氣故 解你 表證 以戒哀遠怒 兼言之也.

8) 『東醫壽世保元 辛丑本』「太陰人 肝受熱裏熱病論」 13-18 論曰太陰人面色青白者多無燥症 面色黃赤黑者 多有燥症 蓋肝熱肺燥而然也
大黃을 1 錢 加한 처방으로 太陰人의 中腑二便閉,

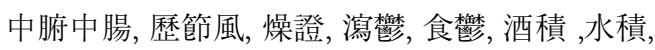
蟲積, 中消, 夢遺, 白淫, 氣痛, 癲癎, 癲狂, 吐血,

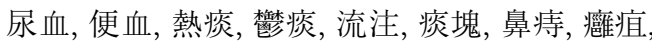
등에 쓸 수 있다고 하였다. ${ }^{16}$ 淸肺瀉肝湯은 급성기 중풍에 가장 많이 사용되고 있는 처방 중 하나로 중풍 의 진행을 억제시키는 효능이 있으며, ${ }^{17}$ 섬망 ${ }^{18}$, 다발성 근염 ${ }^{19}$ 등 다양한 증상에 사용한 증례가 보고되어 있 다. 그러나 惡食이나 食慾不振 등의 증상에 응용한 치험례는 찾아보기가 힘들었다.

牛黃清心元은 卒中風으로 人事不省이 되고 痰涎이 막혀서 정신이 흐릿해지는 등의 증상을 치료 하는 처방 ${ }^{10}$ 으로 중풍후유증의 범주에서 牛黄清心 元을 함께 사용하였다.

환자의 증상은 식사량의 변화를 기준으로 했을 때, 입원 4일째부터 조금씩 호전을 보이기 시작하여 6일 만에 처음으로 식사를 시작하였으며 입원 5일째부터 10 일째까지는 매 끼니 죽으로 $1 / 2$ 공기 정도씩 규칙 적으로 식사를 하였다. 그리고 입원 11 일째 저녁부터 는 밥으로 식사를 하였고 이후 매 끼니 밥1/2 1공기 이상의 식사를 하였으며 퇴원일에도 밥 $1 / 2$ 공기 이상 의 식사량을 유지하였다.(Figure 2)

惡食症 이외의 증상들 중, 眩暈, 氣力低下 의 증상은 입원 4 일째에 식사를 시작한 이후로 호전되는 양상을 보였다. 그러나 不眠 증상은 입원할 당시에 비해서는 상당히 호전되었지만 여전히 깊은 잠을 자 지 못하고 자다 깨다 하는 상태를 보였다. 입원 11 일째 에는 眩暈, 氣力低下 및 頭痛 증상이 모두 소실되었 다. 하지만 여전히 숙면을 취하는데 어려움이 남아있 었다.(Table 2) 퇴원 시에 淸肺瀉肝湯과 牛黃清心 元을 2 주 분량 추가로 처방하여 복용하도록 하였고, 2 주 후에 환자의 상태를 전화 추적해 본 결과, 식사도 무리 없이 하고 있으며 잠도 잘 잔다고 하였다.

본 증례는 뇌경색 발병 한달 후에 惡食症이 발생 한 환자의 경우로 환자는 밥뿐만 아니라 약, 물 등의 모든 음식물 섭취를 전적으로 거부하는 증상을 보여 주로 볼 수 있는 식욕부진 환자의 증상과 달랐으며 
그 원인 또한 惡食의 일반적인 원인인 傷食이 아니 라 정서적 스트레스로부터 비롯된 경우로 $\mathrm{BDI}$ test에 서도 심한 우울증으로 확인되었다. 이 환자를 性情의 偏急으로 인해 惡食症이 생긴 것으로 보아, 이를 裏 熱病의 범주에서 보고 太院人 燥熱證에 쓰는 처방 인 淸肺瀉肝湯을 투여하여 환자의 주소증 및 제반 증상들이 호전된 경험이 있기에 보고하는 바이다.

\section{IV，參考文獻}

1. Traditional medical science Institute. Oriental medicine unabridged dictionary. Seoul:Seongbosa. 2000:1572. (Korean)

2. Oh G. Uijonggeumgam. Vol 2. Beijing:People health press. 1982:1506.

3. Lee C, Uihakipmun. Seoul:Beopinmunhwasa. 2009: 1199-1200.

4. Jang GB. Gyeongakjeonseo. Seoul:Iljungsa. 1993:271.

5. Lee YS. Jeungchihwibo. Hongkong:Manyeop press. 1975:99.

6. Korean stroke society. Text of Stroke. Seoul:E public. 2010:419-420. (Korean)

7. Kim KS, Suo KS, Kim DW, Shin SH, Han MA, Jung YJ, et al. Clinical study on the complication after stroke. J Korean Oriental Med. 2000;21(2):227-235. (Korean) 8. Ji JG. Medical terms unabridged dictionary. Seoul: Academia press. 2004:114. (Korean)

9. Shin HG, Ryu BH, Park DW, Ryu KW, Jang IK. A philological study on the anorexia. J Korean Oriental
Med. 1987;8(1):82-87. (Korean)

10. Heo J. Donguibogam. Seoul:Beopinmunhwasa. 2007: 1215.

11. Chinese medical science institue. Chinese medicine symptoms Differential diagnosis. Beijing:People health press. 1987:254.

12. Yu BC, Kim JW, Shim JC, Kim MS, Oh BY, Lee JY, et al. A clinical study of one patient suffering anorexia nervosa-like symptoms. Korean J Orient. Int. Med 2004;25(3):655-661. (Korean)

13. Tierney. Current medical diagnosis \& treatment. Seoul: Hanuri Publisher. 1999:1324-1325.

14. Lee SH, Chung HY. Brain neurologic disorder and depression in eldery. Korean Association for Geriatric Psychiatry. 2003;7(2):132-142. (Korean)

15. Lee JM. Donguisusebowon. Seoul:Yeogang press. 2003: 68-69,230,259.

16. Won DP. Donguisasangsinpyeon. Seoul:Haedonguihaksa. 1999:80-178, 194-195.

17. Choi DJ, Jung WS, Moon SK, Cho KH, Kim YS, Bae HS. The Clinical Effecacy on Chupyesagang-tang on Acute Stroke. J Korean Oriental Med. 2002;23(4): 9-14. (Korean)

18. Ban DJ, Lee HS, Kang TG, Han KS, Bae HS, Park SS. The Case Reports of Two Taeumin Delirium Patients. J Sasang Constitut Med. 2007;19(3):257-269. (Korean)

19. Kim MG, Choi JR, Bae HS, Park SS. A case study of multiple myositis. J Sasang Constitut Med. 2003; 15(2):117-123. (Korean) 